\title{
LONG-TERM UNEMPLOYMENT OF THE RISK GROUPS IN THE SLOVAK LABOUR MARKET
}

\author{
Veronika Ladňáková ${ }^{1}$, Martina Špániková ${ }^{2}$
}

\begin{abstract}
Long-term unemployment is a persistent problem for Slovakia. Despite the number of long-term unemployed people in Slovakia has decreased significantly in recent years, it still presents a high proportion of the total unemployment rate. According to the European Commission Report about Slovakia in 2019, while the long-term unemployment rate fell to $4 \%$ on a year-on-year basis, it is still well above the EU average of $2.9 \%$. Although growth is expected in the upcoming years, spending on active labour market policies in Slovakia has been one of the lowest in the EU. The study aims at investigating the current situation of long-term unemployment among risk groups in the labour market in Slovakia and labour market measures taken to curb it. It also examines the consequences of unemployment on the family and to seek solutions for the long-term unemployment in Slovakia. The data has been analyzed by a statistical method and proposes solutions to reduce long-term unemployment in the northern part of Slovakia.
\end{abstract}

UDC Classification: 305-055.1, 305-055.2, DOI: https://doi.org/10.12955/pss.v1.59

Keywords: Active Policy, Family, Labour Market, Long-Term Unemployment.

\section{Introduction}

The loss of a job brings significant changes in all the areas of an individual's life. It causes not only a substantial loss of income but also brings a lot of adverse effects for the individual and his/her family. Although an unemployed person has plenty of leisure time, due to financial insecurity (s)he may lose interest in activities (s)he had been engaged in while being employed. It may result in depression. Working relations will gradually come apart resulting in a lack of interaction, experience and relationships for the unemployed. (S)he may gain another support system from the family members. The longer a person is unemployed, the more (s)he is incapable of planning his/her life effectively (Schraggeová, 2011). Unemployment consequences affect all areas of an individual's life and may create very demanding life situations as well (Vaska, 2014).

There are more reasons why it is difficult to find an appropriate job. In the market economy, unemployment referred to as an unperformed job offer. It may arise when the supply of labour force exceeds demand for it. The reasons are still the same as were in the last decade. For example, Globalisation has resulted in shifting the production base from the countries with high labour costs to the countries with cheap labour costs. In the country of origin, unemployment rises if no alternative solutions are offered. The disproportionately low labour remuneration will lead to a decline in demand for goods and services in the consumer market and subsequently will create labour force surplus. Due to low wages, there will be a lack of interest in a job search. This situation can lead to other problems (e.g. "grey economy"). Another cause of unemployment is a lack of qualification and inefficient educational structure leading to insufficient competitive ability. The technical advancements may often reduce the need for manpower because of the labour effectivity enhancing. We can also count to the above-mentioned issue, structural changes caused by the disappearance of some productions, industries, or sectors where another labour supply is not suitable or is missing at all. This fact occurs very often in the case of the primary sector (Hetteš, 2013).

Another threat which is currently affecting the global labour market is the global pandemic of COVID 19. It has emerged out as a global challenge. The initial months into the pandemic indicated not only the fragility of the system, but also highlighted the need for important changes to be made in the national economic structure. The impact on a higher level of unemployment will be considerable in the close future.

\section{The Risk Groups in the Labour Market}

Unemployment does not impact all groups in the same way. An individual's chances of getting good placement opportunities in the labour market are influenced by the following factors: gender; age; health condition; education; and ethnic origin. These factors pose challenges to the disadvantaged groups in the labour market and therefore they are at a higher risk of job loss. The disadvantaged

\footnotetext{
${ }^{1}$ Catholic university in Ružomberok, Faculty of Pedagogy, Department of Social Work, ladnakova.veronika@gmail.com

${ }^{2}$ Catholic university in Ružomberok, Faculty of Pedagogy, Department of Social Work, martina.spanikova@ku.sk
} 
groups are predestined to long-term unemployment or to the frequent job loss. Thus, they are also labelled as risk groups and in Slovak legislation they are termed as disadvantaged job seekers. According to Article 8 of Act No. 5/2004 Coll., on employment services, the disadvantaged job seeker is considered to be (1) a citizen under the age of 26 who has completed the continuous vocational training less than two years ago and has not yet had a job a graduate; (2) a citizen over the age of 50; (3) a citizen registered as a job seeker for at least 12 consecutive months (long-term unemployed citizen); (4) a citizen who has completed lower than secondary vocational technical education; (5) a third party national; (6) a citizen single adult with small children and (7) a citizen with disabilities.

All the disadvantaged job seekers need individual |attention from the social workers dealing with them. Under the scope of social work, it is important to find the right way to lend a helping hand to the citizens who are at risk of unemployment. It does not matter if he or she has a lower qualification or suffers from various kinds of disabilities. Regardless of the risk groups, it is important to find an effective way of client assistance (Vaska, 2014).

\section{Family and Long-Term Unemployment}

Unemployment of a family member disturbs the family life and often result in stressful situations. Each family should be treated individually and therefore the coping mechanism should vary from family to family. Family relations, social, economic and other factors which affect the family life should be taken into consideration. It is necessary to put the accent on such cases where a major crisis may occur and may lead to family's break up.

The unemployment experience differs from individual to individual. A family crisis may arise due to financial hardships caused by. Other issues that should be taken into account are physical and psychological health condition. All these problems are interconnected and it is often difficult to classify them in terms of category, problem types or problem consequences (Schraggeová, 2011).

In general, the consequences of unemployment refer to short-term or long-term stress which is hard to cope with. It affects not only mental but also physical health. The research on the topic revealed that long-term unemployment affects the overall health condition of people at different ages. Major findings from the previous research are as follows:

- The unemployed people suffer from high level of mental discomfort, anxiety and depression. They lose confidence and self-esteem. Middle-aged people find it more difficult to cope with long-term unemployment because it affects their comfort level, well-being and health. Younger and older people can adjust faster (Buchtová et al., 2013).

- Experience of unemployment is an individual matter. People who are dedicated to their occupation suffer from higher risk of mental disorder when losing their job. Middle-aged men deal with job loss harder and they indicate higher risk of mental problems than younger and older people. In most of the cases, they are the breadwinners; therefore, it is difficult for them to deal with it (Matoušek, Pazlarová et al., 2014).

- Unemployment is a challenging period for everybody but the ability to accept it depends on the one's perception of it and what value has been attached to it. Positive social environment including an individual's emotional support system, honesty and participation in the collective work affect his/her mental health in a positive way (Mydlíková, 2018).

\section{Active Policy of Labour Market}

Fridrichová (In Hamráčková, 2013) stated that labour market policy (employment policy) is a support system for the citizens to enhance their active inclusion in the labour market. The Labour market policy should ensure the rights to employment for all people in the working age through policy implementations, occupation mediation and counselling. The state obviously pays a lot of attention to the category of the long-term unemployed. Its primary indicator is the long-term unemployment rate, which is defined as the percentage of the unemployed for 12 months and more in the economically active population.

Kollár (2014) claimed, that active labour market policy uses various methods (retraining courses, activation allowance etc.) and is mainly focused on active labour market participation. Disadvantaged citizen groups are prioritized. Measures such as allowances and programmes are aimed at increasing employment rate. Particular benefits may be divided into two groups: first aimed at citizen's assistance and the other aimed at employer's support. The most frequently used citizen's benefits are: partial 
reimbursement of travel costs, educational allowances, labour-market-preparation reimbursements, self-employment allowances, graduate work experience allowances, activation work in the form of smaller municipal services for municipalities or self-governing regions, activation work in the form of volunteer service, allowances for citizens' work mobility support and last but not least the reimbursements for disabled citizens to start up their own business (Kuchař et Vaska, 2014).

The employers can also receive the benefit for employing job seekers, for creating a new vacancy and for providing employment development support.

The active labour market policy tools include retraining and competence courses for job seekers, job placement, information and counsellor services, professional counselling services, projects and programmes (Act No. 5/2004 Coll.). It refers to the national projects funded by the European Social Fund for employment and education active policy. Several national projects have been launched in Slovakia from the operation programme. They are focused primarily on the disadvantaged job seekers.

Slovak legislation allows non-state employment services as well. These services can be provided by non-state providers (natural persons or corporate bodies) carrying out paid job mediation or supporting job mediation. Social policy is closely linked to unemployment policy in the area where the present study has been carried out. It is thus an important part of any government policy to raise the individual standard of living for the long-term interests of society as a whole (Kamanová, 2016).

\section{Long-Term Unemployment Family Impact Research}

The present study assesses the impact of long-term unemployment on families and coping strategies in Slovak from 2018-2019. The sample consisted of 247long-term unemployed citizens, registered at five offices of Labour, Social Affairs and Family in Žilina self-governing region of Central Slovakia.

Under the scope of the study, the main objective was to find out how and in what areas the unemployment disrupts mutual family relationships. The secondary objective was to answer the question: In what way and by the usage of what means is a long-term unemployed person trying to solve the unfavourable life situation? According to this assignment, the research questions were stated. Their evaluation is possible to see below.

\section{Research Methodology}

A questionnaire was used for gaining multiple responses from the respondents. Following research process was used for obtaining and assessing of the data:

- Analysis - collected data has been interpreted to achieve the objectives of the study,

- Synthesis - the major findings have been summarised,

- Relevant statistical tools have been used for data analysis,

- Induction and deduction were used to generalize the conclusions from the study,

- Comparison - comparisons were made to understand the relationships between variables under study,

- Generalization -finally the results of the study are generalized by drawing broad inferences from the results

\section{Sample:}

The sample was chosen by randomly according to time and spatial possibilities of the Offices. It consisted of 247 long-term unemployed people (68\% women and 32\% men). Age wise $9.72 \%$ of respondents were in the age group of $18-30$ years, $22.67 \%$ in the age group of $31-40$ years, $28.74 \%$ in the age group of $41-50$ years, and $38.87 \%$ of the respondents were at the age of 51 years and above.

Education qualification wise $20 \%$ of respondents have completed their primary education, $25 \%$ were having secondary education completed with the apprenticeship certificate, $33 \%$ with secondary school education completed with the school leaving examination, 5\% with first stage education and $17 \%$ of the respondents had second stage education.

The research also examined the length of unemployment in different age groups. The majority of youngest respondents $(70.83 \%)$ in the age group of 18-30 years have stated that they remain unemployed before getting a job for at-least 12 months. Half of the respondents in the age groups of 31-40 years and 41-50 years the unemployment length of two years and more is prevalent. While more 
than $70.83 \%$ respondents in the age group of 50 years and more stayed unemployed for 2 years and more.

\begin{tabular}{|c|c|c|c|c|c|}
\hline \multirow{2}{*}{$\begin{array}{l}\text { The Length of } \\
\text { Unemployment in the age } \\
\text { group of } \\
\mathbf{1 8} \text { - 30 years } \\
12 \text { months } \\
\end{array}$} & \multicolumn{2}{|c|}{$\begin{array}{c}\text { Number of } \\
\text { respondents / \% }\end{array}$} & \multirow{2}{*}{$\begin{array}{l}\text { The Length of } \\
\text { Unemployment in the age } \\
\text { group of } \\
\text { 31 - } 40 \text { years } \\
12 \text { months } \\
\end{array}$} & \multicolumn{2}{|c|}{$\begin{array}{c}\text { Number of } \\
\text { respondents / \% }\end{array}$} \\
\hline & 17 & $70.83 \%$ & & 9 & $16.07 \%$ \\
\hline $1-2$ years & 2 & $8.33 \%$ & $1-2$ years & 19 & $33.93 \%$ \\
\hline 2 and more years & 5 & $20.84 \%$ & 2 and more years & 28 & $50.00 \%$ \\
\hline Total & 24 & $100.00 \%$ & Total & 56 & $100.00 \%$ \\
\hline $\begin{array}{l}\text { The Length of } \\
\text { Unemployment in the age } \\
\text { group of } \\
41 \text { - } 50 \text { years }\end{array}$ & \multicolumn{2}{|c|}{$\begin{array}{c}\text { Number of } \\
\text { respondents / \% }\end{array}$} & $\begin{array}{l}\text { The Length of } \\
\text { Unemployment in the age } \\
\text { group of } \\
51 \text { years and above }\end{array}$ & \multicolumn{2}{|c|}{$\begin{array}{c}\text { Number of } \\
\text { respondents / \% }\end{array}$} \\
\hline 12 months & 12 & $16.90 \%$ & 12 months & 13 & $13.54 \%$ \\
\hline $1-2$ years & 24 & $33.80 \%$ & $1-2$ years & 15 & $15.63 \%$ \\
\hline 2 and more years & 35 & $49.30 \%$ & 2 and more years & 68 & $70.83 \%$ \\
\hline Total & 71 & $100.00 \%$ & Total & 96 & $100.00 \%$ \\
\hline
\end{tabular}

Additionally, another significant aspect related to the registration frequency of job seekers have been examined. In the present study, it is found that only $23 \%$ of respondents have registered for the first time, majority of them (44\%) have registered for the second time while $33 \%$ of the respondents have registered for the third time and more.

\section{Research Findings and Discussion}

\section{How and in what areas does unemployment disrupt the family relationships?}

$26 \%$ of respondents confirmed that there is a higher level of tension and stress in the family when a family member is unemployed for longer period of time. $21 \%$ of respondents acknowledged that due to unemployment they suffer from inferiority complex within the family. But the family attitude has not found to be very negative. $25 \%$ of respondents mentioned that due to unemployment their family relations had changed only minimally while $21 \%$ of respondents claimed that it has not changed anything in their family. 30\% of respondents found their family supportive and motivating. $29 \%$ of the respondents confirmed the support of their family in job search. As per the results of the study there is no major negative impact of unemployment on families rather it has been very supportive to the unemployed family member. But despite of support, it is considered to be natural that the tension and stress are perceptible.

\section{How does the long-term unemployed cope with this unfavourable situation in life?}

$53 \%$ of respondents emphasized big importance of the Office of Labour, Social Affairs and Family employees in job seeking process and they searched for a new job through this institution. $28 \%$ of respondents claimed that they were looking for jobs on the Internet. Long-term job seekers trusted the institution that provided them an employment opportunity or at least, assisted them in job search. 66\% of respondents wanted to help the family in the financial matters, because they suffered from money shortage. They were happy if they could fulfil all the family needs. The primary motivation objective was material security for the family.

Only $21 \%$ of respondents were active job seekers, looking for vacancies intensively every day. While majority of $35 \%$ of respondents were looking for job only once a week.

$58 \%$ of respondents were interested in retraining courses which may be helpful in job placement at the labour market. Retraining courses are very suitable for the majority of job seekers with lower education. These courses help them in gaining a lot of experience and skills for their self-development and carrying out their chosen job. This decision can be useful from the financial point of view as well.

$21 \%$ of respondents showed keen interest in a language or a nursing course. Majority of the respondents (48\%) did not know which course would be the most appropriate for them, but from their 
responses, it was clear that they were aware of its advantages as it was the fastest alternative to enhance their qualification. The other popular courses among job seekers were: massage therapist, make-up artist, hairdresser, security services, operating $\mathrm{CNC}$ machines and communication skills.

According to the research findings, the job seekers insisted on financial security for their family. They preferred retraining courses where they were able to obtain sufficient skills, experiences and knowledge in the shortest period of time. And it would help them in finding a suitable job.

What are the coping strategies used by the long-term unemployed?

As many as $31 \%$ of respondents received the unemployment benefits which can be considered at least as a minimum income. $35 \%$ of respondents had savings from the past and they were able to cover their needs this way. $28 \%$ of respondents stated that they took part in casual work. $12 \%$ answered that their partner worked and provided finances for the family. The last share made money by performing activation work.

Most of the respondents (67\%) could imagine their future occupation outside their qualification or former job. The length of registration did not influence their decision.

For job search, the most preferred way was through the Office of Labour, Social Affairs and Family (76\%), followed by the Internet search and the references of the family. Other sources like national projects being executed by the Offices or various state offered allowances for the startups were not very popular.

The respondents were willing to commute but only to a certain distance. In most cases they did not want to move because of work or they did not consider working abroad.

Counselling services were used by the majority of the respondents and they prioritized the usage of counselling and information services for their career choice. The respondents were mostly satisfied with the above mentioned services and they found them useful in solving the problem of unemployment. However, some of the respondents stated that the Office workers did not offer them jobs appropriate to their qualification. They did not provide them enough information about problem solution or they did not spend enough time with the troubleshooting.

Based on the results of the study, the job seekers received the unemployment benefits which could provide them with a minimum income. The job seekers tried to find at least casual jobs in order to provide financial security for their families. A lot of the unemployed people had savings available, which is assumed to be useful and necessary for better family life.

\section{Conclusion}

Long-term unemployment has a major impact on personal life. It is a challenging period not only for an individual living alone, but also for a person with family. Then (s)he is not the only one who bears the brunt, but the whole family suffers. A family can be very supportive during the crisis, though, it may also end up in broken relationships and may create big problems.

The findings of the study indicated family solidarity during the crisis period. The family members support, motivate and help each other. Unemployed people are more prone to tension and stress. Fortunately, it does not have a bad impact on family relations. The respondents rather pointed at the financial crunch due to which they are unable to meet the basic family requirements.

According to the results, it is recommended for the families to look for professional assistance in the form of counselling to avoid bigger family crises. Disrupted family relationships have not been reported by the respondents. They only feel higher level of tension and stress. To avoid this unfavourable situation, it is advised to start preventing these issues from the very beginning. Group counselling is more appropriate, as the entire family acquires skills of dealing with stressful situations.

In terms of providing assistance to a job seeker, individual social counselling may represent the best way of motivation against financial insecurity. It may be helpful for the client to cope better with the unfavourable situation and to help him/her in job search and orientation at the labour market. (S)he should be prepared to learn new skills and should not forget working habits. (S)he should be motivated and enrol in retraining courses which enhance the chances of finding a suitable job. The financial benefits for the unemployed are limited in Slovakia, thus each opportunity should be taken seriously.

A person with the status of "unemployed" in Slovakia has a limited opportunity to increase their income. He may work in an employment relationship on the basis of an agreement on work performed 
outside the employment relationship. But he can work a maximum of 40 days in a calendar year. It is advisable to be informed about this possibility as well.

The Office of Labour, Social Affairs and Family employees should inform the long-term unemployed about the provision of commuting allowances. Majority of the respondents showed interest in this form of benefits. The attention should be drawn on the national projects, retraining and competence courses by promoting these in media and advertisement.

\section{References}

Buchtová, B., Šmajs, J., \& Boleloucký, Z. (2013). Nezaměstnanost. Praha: Grada Publishing.

Hamráčková, M. (2013). Sociálna práca s nezamestnanými a kvalita života nezamestnaných. Nitra: Univerzita Konštantína Filozofa.

Hetteš, M. (2013). Zamestnanost’ a sociálna práca. Bratislava: Vysoká škola zdravotníctva a sociálnej práce sv. Alžbety.

Kamanová, I. (2016). Sociálne služby. In V. Hulínová, \& L. Štefáková, Metódy a metodika sociálnej práce II. (pp. 61-85). Ružomberok: VERBUM.

Kollár, T. (2014). Nezamestnanost' a stratégie jej zvládnutia. Levoča: MTM.

Kuchař, P., Vaska, L., \& al. (2014). Regionálne aspekty nezamestnanosti v Českej republike a na Slovensku. Bratislava: IRIS.

Matoušek, O., Pazlarová, H., \& al. (2014). Podpora rodiny. Praha: Portál.

Mydlíková, E. (2018). Posudzovanie sociálnej rizikovosti rodiny. Trnava: Trnavská univerzita.

Schraggeová, M. (2011). Nezamestnanost'v psychologických súvislostiach. Nové Zámky: Psychoprof.

Štefáková, L., \& Bernoláková, L. (2015). Potreba sebarealizácie a zmysluplného využívania vol’ného času u seniorov. In Wybrane aspekty opieki nad osobami starszymi z perspektywy opieki zdrowotnej i pracy socjalnej (pp. 64-93). Brno: Tribun EU.

Act No. 5/2004 Coll. (2004) THE ACT No 5/2004 Coll. on Employment Services and on the amendment to certain acts as amended by later regulations.

Vaska, L. (2014). Služby zamestnanosti a vybrané aspekty sociálnej práce s nezamestnanými. Bratislava: IRIS. 